\title{
El indulto en la jurisprudencia de la Corte Suprema de Justicia
}

The pardon in the jurisprudence of the

Supreme Court of Justice

o perdão na jurisprudência do Supremo

Tribunal de Justiça

La grâce dans la jurisprudence de la

Cour suprême de justice

最高法院判例中的赦免。

\section{Esteban Federico Taglianetti ${ }^{1}$ Universidad Nacional de La Plata}

Revista Derechos en Acción ISSN 2525-1678/ e-ISSN 2525-1686

Año 4/No 12 Invierno 2019 (21 junio a 20 septiembre), 414-458

DOI: https://doi.org/10.24215/25251678e312

ORCID: https://orcid.org/0000-0001-5809-9881

Recibido: 03/03/2019

Aprobado: 16/05/2019

Resumen: En el presente trabajo, partiremos citando y comentando una selección de los principales fallos de la Corte Suprema de Justicia en materia de indulto y conmutación de penas, con el propósito de analizar las citadas figuras a través del paso del tiempo y de subrayar, también, la importante incidencia que tuvieron los tratados internacionales de derechos humanos en las resoluciones de la Corte Suprema argentina. Luego, haremos hincapié en la importancia que reviste excluir los delitos graves del alcance del indulto y la conmutación de pena, para finalmente concluir dejando sentada nuestra opinión en relación con la necesidad de que, durante el procedimiento previo al dictado del acto, existan audiencias públicas y, a su vez, medie una participación efectiva de las

1 Procurador (UNLP), Abogado (UNLP), Especialista en Derecho Administrativo (UCALP), Especialista en Derecho Constitucional (UNLP). Actualmente, cursando segundo año en la Maestría de Derecho Procesal (UNLP). 
víctimas del delito perpetrado por el candidato a ser beneficiado con el indulto.

Palabras claves: indulto - conmutación de pena - jurisprudencia de la Corte Suprema argentina - atribuciones del Poder Ejecutivo - derechos humanos

Abstract: This abstract firstly quotes and comments on a selection of the main rulings of the Supreme Court of Justice regarding pardon and commutation of sentence, with the purpose of assessing these concepts over time and highlighting the importance international human rights treaties hadin the decisions of the Supreme Court of Argentina. Secondly, it emphasizes the importance of excluding serious crimes from pardon and commutation of sentence. Finally, it raises the need for public hearings during the procedure prior to court decision and foran effective participation of the victims of the crime perpetrated by the beneficiary of the pardon.

Keywords: pardon- commutation of sentence - jurisprudence of Supreme Court of Argentina- powers of the Executive Branch - human rights.

Resumo: No presente trabalho, vamos começar por citar e comentar uma seleção das principais decisões do Supremo Tribunal de Justiça em matéria de perdão e comutação de penas, com o objetivo de analisar as mencionadas figuras através da passagem do tempo e sublinhar, também, o importante impacto que tiveram os tratados internacionais de direitos humanos nas resoluções do Supremo Tribunal da Argentina. Em seguida, enfatizaremos a importância de excluir os crimes graves do escopo do perdão e da comutação da pena, para finalmente concluir deixando clara nossa opinião em relação com a necessidade de que, durante o procedimento anterior à emissão do ato, se realizem audiências públicas e, por sua vez, exista uma participação efetiva das vítimas do crime perpetrado pelo candidato a ser beneficiado com o perdão.

Palavras-chave: perdão - comutação de sentença - jurisprudência do Supremo Tribunal da Argentina - poderes do Poder Executivo - direitos humanos.

Résumé: Dans le présent travail, nous commencerons par citer et commenter une sélection des principales décisions de la Cour suprême de Justice en matière de grâce et de commutation de la peine, dans le but d'analyser les figures susmentionnés dans le temps et de souligner, aussi, 
l'impact important que les traités internationaux relatifs aux droits de I'homme ont eu sur les résolutions de la Cour Suprême argentine. Ensuite, nous soulignerons l'importance d'exclure les crimes graves du champ de la grâce et de la commutation de peine pour enfin conclure en affirmant notre position sur la nécessité de tenir des audiences publiques au cours de la procédure précédant la publication de l'acte. et, en même temps, assurer une participation effective des victimes du délit commis par le justiciable susceptible de bénéficier de la grâce.

Mot-clés: grâce - commutation de peine - jurisprudence de la Cour Suprême argentine - attributions du Pouvoir Exécutif - droits de l'homme

摘要: 在目前的工作中, 我们将首先引用和评论最高法院在赦免和减 刑方面的主要决定的选择, 目的是通过时间的推移分析上述数字, 并 强调, 国际人权条约对阿根廷最高法院决议的重要影响。然后, 我们将 强调将赦免和减刑范围中的严重犯罪排除在外的重要性, 最后通过在 行为发布前的程序中留下我们对公开听证会需要的意见来结束。反过 来, 调解候选人犯下的罪行受害者的有效参与, 以使赦免受益。

关键字: 赦免, 减刑, 阿根廷最高法院的判例, 行政部门的权力, 人权

\section{Objeto}

Desde un punto de vista académico y práctico, conocer la opinión del Superior Tribunal es siempre un ejercicio intelectual necesario e interesante, por esta razón, en el presente trabajo, pasaremos revista por los principales fallos de la Corte Suprema de Justicia en materia de indulto y conmutación de penas, con el propósito de ofrecer un análisis de las citadas figuras. Específicamente, pretendemos describir, a partir de sentencias significativas de nuestra vida institucional, el perfil que los institutos mencionados fueron adoptando a través del paso del tiempo, evaluando también el modo en que la irrupción que los tratados internacionales de derechos humanos han incidido en los fallos del Tribunal Supremo.

El trabajo se estructurará de la siguiente manera: a modo de introducción, iniciaremos nuestro estudio definiendo las figuras 
del indulto y la conmutación de penas y diferenciándolas del instituto de la amnistía. Luego, listaremos los fallos de la Corte Suprema presentándolos en orden cronológico, analizando en cada caso su particularidad y relevancia. Por último, en una tercera instancia, daremos cuenta de nuestras conclusiones, dejando sentada nuestra opinión en relación con la necesidad de que, durante el procedimiento previo al dictado del acto, existan audiencias públicas y medie una participación efectiva de las víctimas del delito perpetrado por el candidato a ser beneficiado con el indulto.

\section{Definiciones de los institutos: indulto, conmutación de penas y amnistía}

En el artículo 99 inciso $5^{\circ}$, la Constitución Nacional faculta al Poder Ejecutivo de la Nación a indultar y conmutar penas, en los siguientes términos: "Puede indultar o conmutar las penas por delitos sujetos a la jurisdicción federal, previo informe del tribunal correspondiente, excepto en los casos de acusación por la Cámara de Diputados". Cabe agregar que, mientras el indulto consiste, básicamente, en un perdón o gracia de la pena impuesta por sentencia firme, la conmutación de penas supone la modificación de una pena por otra menor, ya sea en el "quantum" o en la calidad de la pena. Es pertinente mencionar que, al conmutarse la calidad, ambas penas deben estar previstas como alternativas en el tipo penal en cuestión (por ejemplo, multa y prisión), pues, en caso contrario, el Ejecutivo estaría irguiéndose en legislador. Con respecto al indulto, es necesario agregar que el artículo 68 del Código Penal estipula que este instituto extingue la pena y sus efectos, con excepción de las indemnizaciones debidas a particulares.

Con respecto a la amnistía, el texto constitucional, en su artículo 75, inciso 20, otorga al Congreso de la Nación la atribución de "conceder amnistías generales". Desde nuestro punto de vista, la amnistía es el acto constitucional por el cual el Congreso decide extinguir acciones penales y penas que se 
hubieren impuesto a los autores penalmente responsables. A diferencia del indulto y la conmutación de penas, la amnistía extingue la acción penal y hace cesar la condena y todos sus efectos, excepto las indemnizaciones civiles que puedan corresponder a terceros (Código Penal, artículo 61). Al decir de Lazzarini (1989), la amnistía es la "ley de olvido, que trae aparejada la amnesia total de una o varias acciones penadas, como si no hubiera existido y lo actuado no hubiera sido punible, de ahí que se diga con razón, que borra la acción penal y si hubiera dictado sentencia, también a ésta" (p. 1117).

En síntesis, podemos afirmar que, así como la concesión de amnistías es una atribución del Congreso, el indulto (individual y total) y la conmutación de penas (individual y parcial) figuran como competencias del Poder Ejecutivo, por disposición del constituyente.

\section{Jurisprudencia de la Corte Suprema respecto del indulto}

A continuación, glosaremos los fallos más destacados del Máximo tribunal federal. Como anteriormente señalamos, esta revisión histórica es necesaria para ofrecer un análisis detallado de la evolución de los institutos analizados.

\section{III.1. Los casos “Criminal c/ Bianchi, Alejo" (Fallos: 3:87)2 y “Criminal c/ Estrella, modesto y Echevarrieta, Ramón Segundo" (Fallos: 29:330)}

Este caso se inicia cuando Alejo Bianchi, empleado de la Aduana, se apoderó ilegalmente de una botella de aceite tomada de los depósitos del organismo público. Como consecuencia de

2 Para Ramella (1982) existe un antecedente previo al caso "Bianchi". Al respecto, el
constitucionalista se pronuncia del siguiente modo: "En un primer caso (Antonio Magdalena)
no hubo estrictamente, decisión judicial. Condenado el referido Magdalena por el Juez del
crimen, el presidente Yrigoyen solicitó informes a la Cámara de Apelaciones, la que contestó
que no podía evacuarlo y ante la insistencia del poder ejecutivo replicó que de acuerdo a las 
su accionar, se realizó un sumario en el que constaron diversas pruebas testimoniales en su contra y, también, su propia confesión. El Procurador Fiscal, atento a las pruebas reunidas y a la comprobación del hecho delictivo, acusó a Bianchi de hurto y pidió la aplicación de la pena prevista en el artículo 81, inciso 2, de la ley penal del 14 de septiembre de 1863.

Ante dicha situación, el defensor del encartado señaló que, por la insignificancia del hecho, no podía condenarse a la dura pena de tres años de trabajos forzados. Además, puntualizó que la ley penal mencionada no le quitaba al hecho el carácter correccional, pues el delito no cambiaba por el hecho de haberse cometido en la Aduana. El Juez Seccional lo encontró penalmente responsable y fundamentó su decisión en el hecho que no cabe distinción alguna, por la importancia económica de la cosa hurtada, para la imposición de la pena. Contra dicho fallo se alzó el defensor de Bianchi, quien fundamentó su apelación en el hecho de que no se había consumado el delito -habría quedado en grado de tentativa-. El Procurador, por su parte, se opuso y señaló que el fallo era conforme a derecho.

Llamada a resolver el caso, la Corte Suprema indicó, en un brevísimo fallo, lo siguiente: 1) confirmación de la sentencia, en base a las pruebas obrantes en el expediente, y 2) reconocimiento de que, entre los hechos juzgados y el reproche penal, existía una desproporción en la sentencia. Además, tomando en consideración dicha desproporción, promovió que el Poder Ejecutivo hiciera uso de las facultades constitucionales previstas en el artículo 86, inciso 6 (actual, artículo 99, inciso 5), del siguiente modo:

considerando en equidad y fuera del mérito legal de esta causa, que la pena de tres años de trabajos forzados no está en proporción con el hurto cometido de una botella de aceite, y que por esta ratería el delincuente ha sufrido ya seis meses de prisión aproximadamente [...] [invita al

disposiciones constitucionales el presidente no puede arrogarse el conocimiento de causas pendientes" (p. 760). 
Poder Ejecutivo] a ejercer en el presente caso el derecho de indulto que le acuerda la Constitución Nacional (p. 89 y 90).

Por su parte, en la causa "Estrella, Modesto y Echevarrieta, Ramón", se reitera esta exhortación al Poder Ejecutivo para que utilice el indulto como mecanismo para poner en quicio la situación. La causa tuvo lugar, cuando las personas referenciadas falsificaron monedas con "la coloración y plateado de monedas de cobre de curso legal y la alteración en su tipo con el propósito de hacerlas aparecer como monedas de plata" (p. 330), constituyendo así el delito de falsificación de monedas previsto en la Ley Penal. Previa investigación, se dispuso la condena de cuatro años de trabajos forzados y 500 pesos fuertes de multa.

Ante dicha situación, la Corte sostuvo que: "Considerando en equidad y fuera del mérito legal de esta causa, que la pena [...] no está en proporción con el delito cometido [...] invitase al Poder Ejecutivo de la República a ejercer en el presente caso el derecho de indulto que le acuerda la Constitución Nacional" (p. 337). Es decir, como había hecho en el caso "Bianchi", la Corte, para subsanar la desproporción existente entre el hecho y la sanción prevista- le requirió al Poder Ejecutivo que haga uso de las facultades propias de indultar a los condenados.

\section{2. Caso "Andrade" (Fallos: 11:405)}

En este fallo, la Corte Suprema se encargó de efectuar la necesaria distinción que cabía hacer, en términos constitucionales, entre el indulto y la amnistía. Al respecto, el máximo órgano sostuvo que:

El juez en su sentencia duda que el Comisionado Nacional tuviera facultad para conceder indulto, y en cuanto al Presidente de la República, dice que ha debido esperar a que el acusado fuese juzgado, y dar después el indulto [...] Pero el juez ha confundido torpemente el indulto o conmutación de penas que puede decretar el Presidente en casos particulares sobre reos ya juzgados y culpables, con las amnistías generales, que la política y las 
conveniencias aconsejan dar en muchos casos, y que tienen el efecto de impedir todo juicio y persecución por hechos anteriores (p. 415).

Este fallo reviste, a nuestro entender, relevancia institucional pues, el hecho que subyace a esta intervención, es una clara diferenciación con la Corte norteamericana, que permite al presidente estadounidense tanto indultar como amnistiar, partiendo de una interpretación amplia del texto constitucional de ese país. Por el contrario, nuestro constituyente asignó específicamente la competencia de indultar y conmutar las penas, al Poder Ejecutivo y, la de amnistiar, al Poder Legislativo exclusivamente. Las diferencias fueron respetadas en el fallo y de allí su valor.

\section{3. Caso "Manuel Díaz, criminal contra, solicitando gracia - Artículos 73 y 74 del Código Penal” (Fallos: 120:19)}

En este fallo, la Corte Suprema sostuvo que la finalidad perseguida por el indulto es la siguiente:

prevenir los inconvenientes derivados de la aplicación estricta de las leyes penales que no pueden prever todas las modalidades de los casos particulares o como dice Story, porque ningún sistema de leyes puede proveer para cada matiz posible de culpabilidad, un grado proporcionado de castigo [...] Además, la ley puede ser violada hallándose el culpable colocado en circunstancias que le hagan excusable ante la moral y la justicia absoluta, aunque no ante los términos estrictos de la ley (Comm. 494; The Federalist, $\mathrm{n}^{\circ}$ 74). La penalidad impuesta por la ley puede hallarse en proporción con la gravedad del delito, como ha ocurrido con la de tres años de trabajos forzados aplicada al reo por sustraer una botella de aceite de los depósitos de la Aduana, y con la de cuatro años de la misma pena a los que habían falsificado algunas monedas de cobre, casos en los que esta Corte, al confirmar las sentencias que les aplicaban, ha invitado al poder ejecutivo a hacer uso de la facultad de indultar con lo que ha investido la Ley Fundamental (p. 28). 
Tal como se puede advertir, la importancia de este fallo radica en la especificación de la funcionalidad, a nivel institucional, de la figura del indulto.

\section{4. Caso "Criminal c/Luengo, Simón y otros" (Fallos: 6:227)}

En esta causa, la Corte Suprema confirmó, por sus fundamentos, la sentencia oportunamente dictada por el juez federal de la Provincia de Córdoba, que había dispuesto que el Poder Ejecutivo no podía indultar a quien no ha sido declarado culpable, ni conmutar penas que no hubiesen sido impuestas.

En el fallo se hacen las siguientes afirmaciones: 1) Para que el presidente de la República pueda ejercer la facultad de conmutar o indultar las penas en los delitos sujetos a la jurisdicción federal, es necesario que haya habido un juicio en que se califique el delito, y se designe al delincuente y la pena que debe aplicarse; y 2) El derecho de indultar, acordado por la Constitución al presidente de la República, no puede ser ejercido por un ministro de la Nación, sin previa autorización de aquél (p. 227).

A los fines del presente trabajo, nos parece pertinente transcribir lo siguiente:

el ejercicio del derecho de indultar, atribuido por la Constitución, artículo 86, inciso 6, al Presidente de la República, debe seguir al juzgamiento en el que se ha de calificar primero el delito y se ha de designar el delincuente y la pena; pues de otro modo no podría indultarse en el sentido de la Constitución, y previo informe judicial, a quien no es declarado culpable, o conmutarse penas que no son conocidas ni han sido pronunciadas por la única autoridad a que está reservada esta función, quedando así, por último, invertido el orden natural de las funciones de los poderes públicos y burlados los propósitos de la Constitución. Al mantener ella el derecho de gracia en la forma que lo ha hecho, subordinándolo a una tramitación especial, en que el juzgamiento precede al 
indulto, ha querido, sin duda que éste evite o modifique el excesivo rigor que pueda acompañar a la aplicación de la ley en ciertos casos y circunstancias de que no debe darse cuenta un juez; ha querido que todos y cada uno de los poderes cumplan con su deber en la esfera que les está marcada; que la moralidad se levante en alto; que la ley conserve siempre su prestigio, siendo ciegamente obedecida, y finalmente que la conciencia que inspire el perdón, al dispensar la pena valga como el mismo castigo y nada defraude a la justicia con que se aplica la ley en el proceso (p. 230- 231).

\section{5. Caso "Criminal c/Ibáñez, José y Sengiale, Amedeo" (Fallos: 136:244)}

En el fallo "Ibáñez", la Corte abordó la cuestión referida a la posibilidad de dictar un indulto a quien contaba con un proceso abierto, pero aún no se le había dictado sentencia condenatoria. Asimismo, abrió el debate respecto de si era o no prescindible el informe del Tribunal del juicio.

En nuestra opinión, los hechos de la causa sopesaron de especial manera. En efecto, el encartado, un joven español de 19 años, había hurtado cinco pares de media del comercio donde trabajaba, para dárselas al otro imputado, Sengiale, ${ }^{3}$ que se encontraba en estado de indigencia. Ante dicha situación, el juez de primera instancia, aplicando e interpretando los hechos y el derecho de manera estricta, los condenó a dos años de prisión. Posteriormente, Ibáñez interpuso el recurso de apelación ante la Cámara correspondiente. Ante dicha circunstancia, que tuvo repercusión en la opinión pública, el entonces Presidente de la Nación, Hipólito Yrigoyen lo indultó sin que haya recaído en la causa una sentencia definitiva. La Cámara de Apelaciones entendió que lo hecho por el Presidente era inconstitucional y decidió proseguir con la causa. Entre otros argumentos, sostuvo:

3 En el fallo, se señala que "Amadeo Sengiali o Sengiale, argentino, de diez y siete o diez y ocho años, peón, soltero y domiciliado en la calle Freyre número 1528" (p. 245). 
Que el indulto, por sus orígenes, la razón que lo informa y los antecedentes históricos y de doctrina, importa la indulgencia, la clemencia, la gracia, el perdón, social ejercido por el órgano del Jefe de Estado a favor de aquellas personas a cuyo respecto las leyes penales, en su aplicación a casos concretos, resultan de una severidad imprevista y desproporcionada, y es, por lo tanto, eminentemente subjetivo e individual. Que siendo así, es fuera de duda que el indulto supone como antecedentes un delito y un culpable, pues un perdón sin delito y sin delincuente sería un absurdo, y para que haya un culpable es menester una declaración de responsabilidad, declaración que en todo régimen de gobierno corresponde exclusivamente al Poder Judicial. [...] el indulto sólo procede en virtud del fallo de justicia que declara la existencia del delito, reconoce la responsabilidad del reo y le fija una pena, y que si el Presidente de la Nación pudiese indultar sin sentencia judicial, lo mismo podría indultar sin proceso, lo que evidentemente sería inconstitucional (p. 218 y 219).

En consecuencia, la Cámara, previo dictamen del Fiscal, resolvió "mantener el juicio abierto contra José Ibáñez, en su rebeldía, con arreglo a lo dispuesto en que disponen los artículos 148 y siguientes del Código de Procedimientos, y ordenar se libre oportunamente la orden de captura" (p. 253).

Por su parte, el Defensor del imputado interpuso un recurso extraordinario, que dio lugar a la intervención de la Corte Suprema. El Procurador de la Corte, el constitucionalista José Matienzo, en su dictamen en la causa, manifestó que no existía impedimento constitucional para que se indultara a procesados, recordando la opinión de sus predecesores en el cargo y señalando que él también consideraba como recta doctrina la sentada por el encartado. Básicamente entendía que, según el texto constitucional, fuera de los casos de acusación por la Cámara de Diputados, el Presidente podía indultar o conmutar penas por delitos sometidos a jurisdicción federal, sin excepción alguna, total o parcial, antes o después del proceso. 
En uno de los pasajes del dictamen, el Procurador José N. Matienzo especificó:

La facultad del poder Ejecutivo para indultar, tomada de Inglaterra por los Estados Unidos, fue imitada de la Constitución de esta República por la Constitución Argentina, sin más que dos enmiendas que no afectan al fondo: la una confiriendo expresamente al Congreso el poder de conceder amnistías generales, poder implícito en los Estados Unidos, según los tratadistas, y la otra requiriendo el trámite previo del tribunal correspondiente. Estas dos limitaciones son las únicas en que la Constitución Argentina difiere de la norteamericana en este punto, pues la excepción de que el indulto no procede en los casos de acusación por la Cámara de Diputados es común a ambas constituciones (p. 254).

Posteriormente, el Procurador hizo un pedido de rectificación posterior a la primera sentencia de la Corte, en la cual indicó -a fin de disipar dudas- que:

"A mí modo de ver, la Cámara reconoce que la solicitud de indulto le fue pasada a informe y que ella lo evacuó manifestando que la causa estaba pendiente. Es cierto que, enseguida, la misma Cámara agrega que el indulto se ha producido sin que exista el previo informe que exige la Constitución. Esta segunda afirmación no puede razonablemente tener por objeto destruir la primera, que es de un hecho. Luego, su propósito ha sido calificar jurídicamente ese hecho, negándole el carácter de informe constitucional al evacuado por ella" (p. 258-259).

Llegada la causa, la Corte votó en favor de la constitucionalidad del indulto. La mayoría del tribunal señaló lo siguiente:

"El 'previo informe del tribunal correspondiente' constituye un trámite esencial para el ejercicio de la facultad de indultar que el artículo 86 , inciso $6^{\circ}$ de la Constitución Nacional confiere al Presidente de la Nación. La Constitución Nacional, al no especificar sobre qué puntos ha de recaer el informe que prescribe en su artículo 86, inciso $6^{\circ}$, ha dejado librado a la discreción del Tribunal 
si ha de limitarse a hacer mención de las circunstancias de la causa, como es de práctica (y ocurrió en el caso), o bien si ha de emitir opinión sobre la conveniencia o inconveniencia del indulto solicitado. Para la procedencia del ejercicio de la facultad de indultar, la Constitución requiere que exista causa abierta contra el delincuente, pero no que dicha causa haya alcanzado necesariamente hasta determinado límite del procedimiento, o sea, al de sentencia ejecutoriada; por lo que no es violatorio de la misma el indulto de un procesado respecto del cual sólo existía sentencia condenatoria del Juez del Crimen de la Capital, en apelación ante la respectiva Cámara de la misma" (p. 264) [...] Debe deducirse que el ejercicio de la facultad de indultar es precedente, dentro de los propósitos enunciados en el considerando $5^{\circ}$, cuando existe proceso, ya que antes o después de producida sentencia firme de condenación, puesto que lo que está comprendido en los menos, con tal que preceda el informe del tribunal y no se trate de delitos exceptuados" (p. 264) [...] No puede decirse que los indultos y conmutaciones de penas atribuidas al Poder Ejecutivo, así como las amnistías generales correspondientes al Honorable Congreso, sean contrarias a la separación de los poderes creados por la Constitución, o a la independencia del Poder Judicial, en razón de que, ni el Congreso ni el Presidente en sus respectivos casos, puedan modificar sentencias ejerciendo funciones judiciales con sujeción a leyes vigentes" (p. 265).

Es decir, en el caso "Ibañez", el voto de la mayoría de la Corte Federal dejó sin efecto un indulto concedido, por no haber cumplimentado con el requisito de la previa obtención del informe que debe aportar el tribunal correspondiente. Ahora bien, de los términos del mismo fallo surge que, para la Corte Suprema, aunque no mediase una sentencia condenatoria, el indulto y la conmutación de pena podrían ser válidos.

Por el contrario, la minoría -correspondiente a los votos de los Ministros Méndez y Palacios- observó con claridad meridiana lo siguiente: 
al separar el indulto de la amnistía y al atribuir cada una de estas funciones a un departamento distinto del gobierno, demostraron bien claramente que la facultad que conferían al Poder Ejecutivo no era la prerrogativa de perdonar y de amnistiar que ejercieron los monarcas en el viejo régimen absolutista, y que hacía desaparecer hasta el último vestigio de la infracción, sino la facultad de gracia con el alcance y con el significado que se le daba en el derecho público contemporáneo. Si no hubiere sido éste su propósito, habrían incurrido en manifiesta incongruencia al separar las dos prerrogativas, pues si el Poder Ejecutivo podía conceder amnistías particulares, que tal cosa significa indultar sin sentencia definitiva, aboliendo de hecho los procesos pendientes y las acciones penales, la atribución conferida al Congreso por el artículo 67, inciso 17 in fine de la Constitución resultaría inútil, desde que otro poder del público, con funciones permanentes y más explícito por razón de su composición, tendría derecho de conceder esas amnistías bajo la forma de indultos anticipados y, lo que es más curioso aun, es que tendría el poder de decretar amnistías particulares en contradicción con la cláusula constitucional recordada que exige que tales favores sean concordados con carácter general [...] El Poder Ejecutivo tiene el derecho de indultar penas, pero no tiene el de impedir la imposición de ellas, ni el de suprimir la acción de la Justicia, desde que no está investido de la potestad de borrar la infracción, es decir, de quitar a los hechos delictuosos la calificación que les ha dado la ley. [...] La intervención del Poder Ejecutivo antes de la sentencia, resulta incompatible con la acción independiente y a la vez armónica de los poderes del Estado, y es muy difícil admitir que los mismos constituyentes que declaraban que 'En ningún caso el presidente de la Nación puede ejercer funciones judiciales, arrogarse el conocimiento de las causas pendientes o restablecer las fenecidas', hayan entendido acordarle el medio de suprimir las acciones judiciales y de anular los procesos en tramitación por medio de un indulto prematuro que importa un sobreseimiento (p. 269 y 270). 
El voto de la minoría establece, según nuestro parecer, la correcta doctrina. En efecto, en primer lugar, practica una diferenciación entre la Constitución de los Estados Unidos y la nuestra, aclarando que los alcances de las potestades del Poder Ejecutivo varían notablemente. Además, fija que la competencia está supeditada, entre otros, a que haya recaído sentencia en la causa en la que se determine el responsable penal y una pena pasada en autoridad de cosa juzgada. ${ }^{4}$

\section{III.6. Caso "Don Hipólito Irigoyen. Rechaza el indulto que le fuera acordado por el gobierno provisional de la Nación" (Fallos: 165:199)}

Para comprender acabadamente este fallo debemos hacer referencia a las cuestiones políticas involucradas en la causa. Al respecto, Félix Luna (1993) reseña:

Ya el 31 de diciembre pasado Uriburu había anunciado a Luis Rodríguez Yrigoyen que la libertad de su tío estaba resuelta, aguardándose el momento más oportuno para hacerle efectiva. A mediados de enero se había hablado de una medida general para todos los presos y exiliados, que luego se desmintió. Sólo se dictó un decreto para terminar con la situación del ex presidente, que constituía por sí sola un tremendo baldón contra la dictadura. El decreto expresaba en sus considerandos que 'la detención y proceso del ex presidente don Hipólito Yrigoyen respondió a una penosa e inevitable necesidad, sin que en ningún momento se abrigaran contra él o sus colaboradores designios de persecución o de venganza'. La afirmación era loable, más los traslados, las amenazas, las restricciones y el confinamiento que había padecido el anciano a través de un año y cinco meses no corroboraban lo expresado, sino que, por el contrario, evidenciaban mezquinos propósitos de mortificarlo física y espiritualmente (p. 498).

\footnotetext{
4 Cuando el Presidente Perón indultó a Balbín, quien se encontraba procesado por desacato, hizo referencia a este fallo (v. Decreto $N^{0} 1$ del 2 de febrero de 1951, Boletín Oficial, nº 16.813 del 8 de enero del mismo año).
} 
Obviamente, Hipólito Yrigoyen rechazó el indulto. Según su defensor:

El doctor Hipólito Yrigoyen no puede aceptar ese acto de gracia, que no ha impetrado y que no necesita [...] Buscando agobiar su espíritu y castigar la adhesión innegable de sus conciudadanos, el gobierno 'de facto' por medio de 'comisiones especiales' y de jueces que no son los jueces que la Constitución tiene señalados, creó delitos imaginarios y obtuvo la apertura de un proceso. Ha mantenido esta situación mientras se halló en el poder. Pero a poco de abandonarlo, poseyendo la convicción más absoluta de que la sentencia a dictarse por los propios jueces que había elegido sería absolutoria, ha querido agraviarlo con un indulto que el doctor Hipólito Yrigoyen ni ha pedido ni acepta (citado en Luna, 1993, p. 498-499).

A pesar de lo actuado ante el Poder Judicial, la orden del golpista y usurpador Uriburu debía cumplirse. Así, el viernes 19 de febrero le comunicaron Yrigoyen que debía embarcar rumbo a Capital Federal, cumpliéndose la orden emanada del mencionado funcionario "de facto".

Tiempo después, la Corte volvió sobre el tema del indulto en la causa "Yrigoyen", pero sentenció en un sentido opuesto al que venimos narrando, pues entendió que la facultad de indultar prevista en el viejo artículo 86 inciso $6^{\circ}$ de la Constitución, no autorizaba al Poder Ejecutivo a ejercerla por estar procesado (razón por la cual consideraba que, en este caso, debía existir una sentencia condenatoria definitiva).

La causa, como hemos dicho, se inició cuando el propio Hipólito Yrigoyen se presentó en la Justicia solicitando que se deje sin efecto el indulto de fecha 19 de febrero de 1932, por entender que el mismo resultaba inconstitucional, ya que no respetaba el artículo 86, inciso $6^{\circ}$, de la Constitución Nacional.

El proceso tuvo su derrotero que inició ante un juez de primera instancia donde no se hizo lugar al planteo. Para así resolverlo, el magistrado interviniente sostuvo: 
El defensor del acusado don Hipólito Irigoyen rechaza por su defendido, el indulto decretado en favor de éste por el Presidente del Gobierno Provisional con fecha 19 de febrero de 1932, fundándose en que no lo ha pedido y en que quien lo acuerda es un gobierno de hecho (p. 202).

Posteriormente, menciona al fallo "Ibáñez" para concluir que aunque aparentemente el indulto tenga en circunstancias como la presente el aspecto de un asunto que afecta sólo el interés privado del beneficiado, en realidad la adopción de esa medida puede obedecer a razones de orden político o social que estén por encima de intereses particulares y que sólo el Presidente, de acuerdo, con la interpretación constitucional antes mencionada, está en condiciones de apreciar (p. 203).

En consecuencia, se desestima la oposición formulada por el defensor de Hipólito Yrigoyen.

Presentada la apelación, la Cámara Federal de Buenos Aires se pronunció en contra de la postura mayoritaria del caso "Ibáñez" y declaró la inconstitucionalidad del decreto. Para fundar su decisorio, efectuó una distinción entre los efectos de la amnistía y los del indulto en el derecho constitucional argentino y practicó un destacado análisis de las fuentes. En referencia a la diferenciación aludida, señala:

el Poder Ejecutivo tiene el derecho de indultar penas pero no tiene el de impedir la imposición de ellas ni el de suprimir la acción de la justicia desde que no está investido de la potestad de borrar la infracción, es decir, de quitar a los hechos delictuosos la calificación que les ha dado la ley; y que no es posible que al sancionarse el artículo 86, inciso $6^{\circ}$ de la constitución se haya buscado inspiración en la Constitución norteamericana, cuyo artículo $2^{\circ}$, sección $2^{\circ}$, cláusula $1 \mathrm{a}$. confiere poder al Presidente para conceder perdones por delitos contra los Estados Unidos (p. 205 ).

En cuanto a la fuente del instituto del indulto, el fallo de la Cámara señala: "los constituyentes del 53 no tuvieron el 
propósito de otorgar al Presidente una atribución con la amplitud reconocida por la mayoría de la Corte en el fallo citado" (p. 205-206).

Con estos fundamentos, los magistrados concluyeron que el decreto dictado no se ajustaba al texto de la Constitución y que, en consecuencia, carecía de validez.

A su turno, la Corte Suprema de Justicia sentenció lo siguiente:

Que el indulto difiere de la amnistía sustancialmente en su naturaleza, en su objeto y en sus efectos. El primero significa el perdón de la pena acordado por el P. E. para suprimir o moderar en casos especiales el rigorismo excesivo de la ley, mientras la amnistía es el olvido de un hecho delictuoso, para establecer la calma y concordia social. El primero extingue la pena del indultad; la segunda, la acción y la pena, si antes hubiese sido impuesta, y borra la criminalidad del hecho. El indulto es particular y se refiere a determinada o determinadas personas, la amnistía es esencialmente general y abarca a todos los sujetos comprendidos en una clase de delitos. [...] Por el contario la amnistía es del resorte del Poder Legislativo (artículo 67, inc. 17, Constitución Nacional) único poder que tiene la potestad de declarar la criminalidad de los actos y de crear sanciones, y el único capaz también de borrar sus efectos. [Por último, señala que] el argumento basado en la situación injusta y agraviante en que quedaría el imputado, si el indulto pudiera expedirse antes de la condena, por cuanto todo hombre lleva la presunción de su inocencia mientas no sea convencido de lo contrario, es un valor efectivo y pugna eficazmente contra esa tesis, porque, en verdad, para haber perdón lógicamente se presupone que exista el delincuente y quien fuera indultado llevaría consigo la mancha del delito. No es cierto que siempre quedarían en sus manos los medios para restablecer la verdad o levantar la imputación. La verdad solamente puede surgir de la controversia provocada en el proceso abierto donde el acusador y el acusado discuten libremente, 
desde sus respectivas posiciones, hasta llegar a la dilucidación completa de la conducta del acusado. En la generalidad de los casos la imputación corresponde al Ministerio Fiscal. Perdonando el procesado no tendría éste a quien demandar para levantar la imputación calumniosa de que hubiese sido la víctima, pues jamás hallaría el contendor responsable y autorizado, y quedaría pesando sobre su nombre el proceso que se le formó (p. 211-213).

Finalmente, la Corte alude a la "competencia" del Poder Ejecutivo de Facto en los siguientes términos: "Que el hecho que el indulto "sub lite" haya sido decretado por un P. E. "de facto", no cambia la faz de la cuestión debatida a su respecto, por cuanto el Gobierno Provisional ha podido usar de las facultades del P. E. de derecho, sujetándose en su ejercicio a las prescripciones de la Carta Fundamental y a las decisiones de la justicia (Acordada del 10 de Septiembre de 1930, Fallos, tomo 158, pág. 290)" (p. 213). Este punto, en nuestra opinión, es trascendental para entender el dislate de esta causa: el usurpador indultando al presidente constitucional.

Se puede concluir entonces que, en el presente fallo, la Corte estableció -retornando, así, a la línea originaria en la materia- el estándar por el cual el indulto y la conmutación de la pena no pueden producirse sino después de la imposición de la pena por sentencia firme. Ello así, pues de no darse ese supuesto, se estaría legitimando una intervención indebida del ejecutivo en la esfera de competencias del poder judicial y, además, se generaría lo siguiente:

[una] situación injusta y agraviante en que quedaría el imputado, si el indulto pudiera expedirse antes de la condena, por cuanto todo hombre lleva la presunción de su inocencia mientras no sea convencido de lo contrario, es de un valor efectivo y pugna eficazmente contra esa tesis, porque en verdad para haber perdón, lógicamente se presupone que existe el delincuente y quien fuera indultado llevaría consigo la mancha del delito (p. 213). 


\section{7. Caso "Amorebieta, Valentín Felipe, y otros" (Fallos: 220:730)}

En esta causa, la Corte analizó tangencialmente el tema del indulto y el principio de igualdad, cuando sostuvo:

No existe violación de la igualdad por la circunstancia de que el Poder Ejecutivo de la Nación haya ejercido su facultad constitucional de indultar con respecto a los comerciantes minoristas detenidos preventivamente por infracción a las leyes 12.830 y 12.983 cuyas respectivas causas no se hallaban sometidas aún a los tribunales de justicia (p. 731).

Respecto al indulto como acto privativo del presidente de la Nación, señaló:

La facultad atribuida al P. E. por el artículo 83 , inc. $6^{\circ}$, de la Constitución Nacional, es privativa del mencionado Poder, por lo que el ejercicio discrecional que de ella haga no comporta violación alguna del principio de la igualdad, previsto en el artículo 28 de la Carta Fundamental, ni puede ser objeto de revisión judicial sobre esa base (p. 731-732).

Cabe recordar que otras legislaciones -como la del Estado Plurinacional de Bolivia (Decreto Presidencial 3519)- sortean dicha crítica mediante el establecimiento de condiciones objetivas para alcanzar el indulto -por ejemplo, el establecimiento de penas no mayores a determinada cantidad de años, la condición de no ser reincidente, la exclusión de determinados delitos, etc.-. De esta manera, toda persona que cumpla los requisitos se encuentra en situación de ser indultada o conmutada. Hecho significativo si consideramos que, a fin de año, es habitual que se dicten los indultos individuales a los que reunieran los extremos requeridos.

\section{8. Caso “Lange, Günther" (Fallos: 237:271)}

La Corte Suprema manifestó que el indulto y la conmutación de pena están exentas del control judicial, atento que quedan incluidas en la categoría "cuestiones políticas no judiciables". Al 
respecto, sostuvo: "El ejercicio por el Poder Ejecutivo Nacional o Provincial de la facultad de reducir las penas aplicadas por los tribunales de justicia, es materia reservada a sus titulares y ajena a la jurisdicción de la Corte Suprema” (p. 271).

\section{9. Caso “Carrasco, Juan” (Fallos: 245:12)}

En este caso, la Corte, aborda la cuestión referida a qué jurisdicción deben ser sometidos los penados que están cumpliendo pena, en virtud de una sentencia dictada por sentencia por los tribunales de territorios nacionales, antes de la creación de las nuevas provincias.

En este punto, la sentencia indica que, al no haberse cuestionado la facultad del Gobernador de la Provincia de Formosa para indultar a reos de delitos de carácter común o no federal, cometidos en ese Estado antes de su "provincialización", y al encontrarse los acusados cumpliendo condenas impuestas por los tribunales entonces federales, corresponde que el informe requerido en el expediente de indulto sea evacuado por los tribunales locales competentes y no por la Corte Suprema, que dictó la sentencia definitiva en la causa.

Para finalizar, cabe resaltar que la Corte, teniendo en cuenta el marco jurídico vigente en aquel momento, dispuso que, habiéndose transferido las causas pendientes a la provincia de Formosa, le correspondía a ésta determinar, según el marco constitucional provincial, quién debería analizar la solicitud efectuada por el reo.

\section{10. Caso “García de Rivas, Reina Elvira de Jesús} c/ Nación. Villegas, Andrés Walter. Sarrail, Alfredo Bruno. Álvarez, Juan Carlos. Murúa, Herminio. De la Peña, Julio Arturo" (Fallos: 289:91)

En este fallo, la Corte resolvió que, en virtud de dispuesto en los artículos 478 a 480 del Código de Justicia Militar (vigente en ese momento), el indulto extinguió la pena con todos sus efectos y que, al tratarse de una pena de destitución que incluyó 
la pérdida del estado militar, el indulto implicó la recuperación de ese estado, que supone, entre otros, el derecho de pensión para los deudos.

\section{11. Caso "Solís, Julio Alfredo" (Fallos: 308:1298)}

El fiscal ante la Cámara de Apelaciones Fiscales de Morón, provincia de Buenos Aires, interpuso el recurso extraordinario que le fue concedido, contra la resolución del tribunal que no hizo lugar a un pedido de inconstitucionalidad parcial de la ley $\mathrm{N}^{\circ} 23.070$ y que, en consecuencia, aplicó la mencionada norma al nuevo cómputo de pena. Fundamentó su recurso en que dicha ley vulneraba los artículos 1, 5, $31 \mathrm{y}$ el antiguo 104 de la Constitución Nacional, en cuanto su ámbito de aplicación dispone a todos los condenados con sentencia firme dictada entre el 24 de marzo 1976 y el 10 de diciembre de 1983, pues en definitiva se trataba de una conmutación o reducción de la pena dictada por un órgano constitucional -Poder Legislativo- que carece de dichas facultades.

El fallo es de suma importancia por lo que estaba en juego, ya que la pena impuesta al autor penalmente responsable de los atroces delitos de violación y privación ilegítima de la libertad agravada, en concurso real, fue disminuida en tres días, por la aplicación de un acto del Poder Legislativo que, según el Fiscal, habría invadido facultades exclusivas de los gobiernos provinciales. La Cámara entendió que no se estaba frente a una conmutación de la pena sino ante una forma o modalidad especial de computar los plazos de prisión durante el período y que el Congreso era competente en virtud del viejo artículo 67, inciso 11 de la Constitución.

En nuestra apreciación, sin importar la denominación que le demos, no se modifica su esencia; es decir, se aplicó una conmutación de pena.

La Corte falló confirmando la sentencia de la Cámara, diferenciando las competencias para indultar (individual y personal) de las de amnistiar (general e impersonal). Señaló que "Que, a 
raíz de que la conmutación de pena no está contemplada especialmente en el Código Penal, debe analizarse la situación individual o general contemplada por el beneficio, para determinar si se está en presencia de una amnistía general, o de un indulto o conmutación individual" (p. 1311). Además, en una clasificación que no compartimos, entendió que la conmutación individual era de carácter administrativa, mientras que la conmutación general era de carácter legislativo:

"En ese sentido, cabe destacar que la naturaleza de la conmutación varía según que tenga el ya mencionado alcance general o individual, y que dicha variación modifica también las conclusiones relativas a la jurisdicción. La conmutación como medida individual, es un acto de significación administrativa, que importa el perdón parcial de la pena, por lo que resulta evidente su carácter de medida particular, que es ejercida por el Poder Ejecutivo respecto de penas por delitos sujetos a la jurisdicción federal (art. 86, inc. $6^{\circ}$, Constitución Nacional)" (p. 1311). ${ }^{5}$

\section{12. Caso "Soto, Carlos Raúl c/ Ejército Argentino Estado Nacional s/demanda ordinaria” (Fallos: 313:421)}

En lo sustancial, en la causa, la mayoría de la Corte sostuvo que, pese a que el Poder Ejecutivo podía indultar infracciones, no le era posible hacerlo en materia de jurisdicción disciplinaria militar.

\section{13. Caso "Riveros, Santiago Omar y otros s/privación ilegal de la libertad, tormentos, homicidios, etc." (Fallos: 313:1392)}

En esta causa, la Corte Suprema abandonó la postura adoptada en el fallo "Yrigoyen" y sostuvo que era constitucional

\footnotetext{
5 Ver Ibarlucía, Emilio, Inconstitucionalidad de los Decretos de "indulto" 1002/89, 1003/89 y 1004/89. Violación de la distribución de funciones entre los poderes del Estado que establece la Constitución Nacional, Buenos Aires, El Derecho. Jurisprudencia General, 1990, 135 (revista), pp. 896 y ss.
} 
indultar a procesados. El voto de la mayoría se fundó en que no mediaba perjuicio procesal suficiente en el apelante para cuestionar el indulto. ${ }^{6}$ Mientras que los Ministros Petracchi y Oyhanarte, que acompañaron según su voto, señalaron que: 1) cuando la Constitución hace referencia al término "pena", éste debe ser entendido como el que prevé la ley y no lo que los jueces aplican cuando encuentran responsable a una persona de un delito; 2) no media una violación al viejo artículo 95 -actual 109- de la Constitución, porque el Poder Ejecutivo no "se arroga el conocimiento de causas de que se trate ni abre juicio sobre la culpabilidad del indultado o la falta de ella; al contrario, se aparta de lo jurisdiccional y pone en vigencia una prerrogativa soberana por razones y con fines exclusivamente políticos" (p. 1405); 3) si la persona no fue condenada, por más que haya mediado un indulto, subsiste con total plenitud el principio de inocencia; 4) el orden institucional se trastocaría si los jueces cuestionaran la validez de los indultos. Al respecto, señalaron:

el ordenamiento institucional se vería gravemente subvertido si los jueces tomaran para sí el poder admitir o rechazar las finalidades de ese atributo de la soberanía que es el indulto e invadieran, así, una esfera en que la Constitución quiso que imperara la discreción razonable del Presidente (p. 1403)

\section{14. Caso "Díaz, Claudia Fabiana s/incidente de previo pronunciamiento (indulto)” (Fallos: 314:1440)}

En referencia al indulto como acto político no judicial, la Corte sostuvo lo siguiente en la causa "Díaz":

El indulto como acto de gobierno y por ende de naturaleza política, no puede ser objeto de revisión judicial, sino que sólo cabe examinar las cuestiones jurídicas con él relacionadas. En el caso, la facultad de indultar ha sido ejercida dentro de las exigencias constitucionales

6 En opinión de la mayoría, fueron mal concedidos los recursos extraordinarios que habían sido interpuestos por los representantes de los particulares damnificados. 
dada la existencia del informe previsto en el artículo 86 , inc. $6^{\circ}$, y la discrecional aceptación efectuada por el Poder Ejecutivo, que -al privar de sustento al agravio del representante del Ministerio Público- determina el desistimiento del recurso por parte del Procurador General de la Nación (p. 1440).

\section{15. Caso "Daleo, Graciela Beatriz s/eximición de prisión” (Fallos: 316:507)}

En este fallo, la Corte Suprema reiteró que es constitucionalmente válido indultar a un procesado y, también, trató el tema referido al consentimiento de la persona alcanzada por el "acto de gracia". Respecto a esto último, entiende que no consiste en un acto privado, sino en una potestad pública instituida por la Constitución Nacional, que expresa una determinación de la autoridad final en beneficio de la comunidad.

La Corte sostuvo que el imputado no podía renunciar a los beneficios del indulto. Lo expuso en los siguientes términos:

la institución del indulto en el sistema constitucional argentino no puede considerarse como la sacralización de una reliquia histórica, propia de las monarquías, sin otro fundamento que la clemencia, sino un instrumento de la ley, en correspondencia con la norma de fines de la organización jurídico-política y en particular con la justicia, la paz interior y el bienestar general. En otros términos, no consiste en un acto de gracia privado, sino en una potestad de carácter público, instituida por la Constitución Nacional, que expresa una determinación de la autoridad final en beneficio de la comunidad. [considerando 9 de la mayoría] [...] [en el considerando 10, agrega que] en ese mismo orden de ideas, no cabe otorgarle al indultado la facultad de negarse a aceptar la decisión presidencial, convirtiendo de tal modo en inoperante un instrumento que halla su razón de existir en el objetivo de la pacificación de la República y no como se ha expresado en el beneficio particular del condenado (p. 517.) 
Finalmente, afirma:

Que la Corte Suprema de los Estados Unidos, al interpretar las disposiciones de la Constitución de aquel Estado, las cuales guardan sustancial analogía con las adoptadas por nuestros constituyentes, llegó a idénticas conclusiones. Así, en el caso 'Biddle v. Pertrovich', (274 U.S. 480, 486 del año 1927) aquel tribunal afirmó que: 'En nuestro tiempo un perdón, no es un acto de gracia que casualmente ejerce el poder. Es parte del plan constitucional. Cuando se lo otorga, es la decisión de la autoridad definitiva en el sentido de que el bienestar público estará mejor servido si se inflige un castigo menor que el resultado del fallo'. Mediante ese pronunciamiento se revirtió la doctrina que ese tribunal había sentado en 'Burdick v. United States' (236 U.S., 79 del año 1915), la que propugnaba la existencia virtual de una figura contractual entre el presidente y el indultado, lo que convertía en imperfecto el perdón otorgado sin la debida aceptación. Al respecto de esa superada tesitura se ha dicho que: 'si se [la] siguiera estrictamente en el sistema norteamericano moderno, limitaría indebidamente el uso que el Presidente podría hacer de su poder constitucional de gracia' (Schawartz, Bernard, "Los Poderes del Gobierno", Ed. Universidad Nacional Autónoma de México, t. II, p. 95, México, 1966). A lo que cabe agregar que dejaría en manos del indultado la posibilidad de 'sacralizar su inmolación', con evidente menoscabo de los fines perseguidos mediante la contemplación de ese excepcional instrumento (p. 517-518).

Cabe señalar que, para nosotros, la fuente de nuestro artículo 99, inciso 5, no fue solamente la Constitución de Estados Unidos. Además, como señalamos anteriormente y en otras oportunidades (Taglianetti, 2018), entre el texto norteamericano y la cláusula nacional existen notables diferencias: la amplitud dada a la estadounidense -comprensiva en la práctica tanto del indulto como de la amnistía- permite el indulto tanto a procesados como a condenados. 
Por otro lado, manifestamos nuestra negativa a que se prescinda del consentimiento de la persona. Por el contrario, sostenemos que es un requisito que debe concurrir previamente a la formación de la voluntad del Poder Ejecutivo. Esto se ve con mayor claridad cuando la persona está procesada pues, en ese supuesto, está en juego su buen nombre y honor y, además, se puede preferir que medie una sentencia judicial que determine su inocencia y no que medie un perdón sobre algo que nunca hizo.

Por último, aun cuando se trate de un condenado por sentencia firme, entendemos que debe mediar su previo consentimiento, porque la potestad constitucional del poder ejecutivo no puede avanzar sobre la esfera de libertad y de disponibilidad de la persona. En buen romance, el Poder Ejecutivo no puede "perdonar" a quien niega esa "gracia".

\section{16. Caso "Aquino, Mercedes s/denuncia (Caso Martinelli - Oliva) s/plantea inconstitucionalidad del decreto 1002/89” (Fallos: 315:2421)}

El caso "Aquino" llegó a la Corte luego de que la Cámara Federal de Apelaciones de Bahía Blanca declarara la inconstitucionalidad del decreto 1002/89, que había indultado a los acusados del secuestro y muerte de Laura Martinelli y de la desaparición de Carlos Oliva, entre otras personas. Frente a esto, los defensores de los imputados interpusieron recurso extraordinario.

Del análisis del fallo surge que: 1) el particular ofendido carece de legitimidad para reclamar la inconstitucionalidad del decreto que indultó a un procesado: artículos. 100 bis y 146 del Código de Justicia Militar; 2) aun reconociendo la falta de legitimidad del particular ofendido para reclamar la inconstitucionalidad de un decreto que indultó a un procesado, el dictamen

\footnotetext{
7 En sentido contrario, para Marienhoff (2011), “[e]l carácter de 'orden público' que reviste el indulto lo torna insusceptible de impugnación jurisdiccional a los efectos de su rechazo, 0 de su 'renuncia' [...] por parte del favorecido por él: el indulto existe independientemente de la voluntad del indultado, pues se le emite atendiendo a superiores intereses de la sociedad" (p. 568).
} 
del fiscal resulta, por su naturaleza y contenido, un antecedente apto y suficiente para provocar el pronunciamiento de la Corte; 3) el titular del Poder Ejecutivo está facultado para indultar a personas sometidas a proceso.

Además, en esta oportunidad, luego de hacer un profundo análisis de los antecedentes en materia de indulto a procesados, el juez Fayt configuró el punto 4) del mentado fallo señalando lo siguiente:

el indulto antes de la condena requiere que el delito haya sido cometido previamente y cuanto menos existir semiplena prueba del mismo y elementos suficientes, a juicio del tribunal, para creer al imputado responsable del hecho, toda vez que no se indulta a inocentes (p. 2437).

Por último, en disidencia, votaron los jueces Levene y Belluscio quienes sostuvieron:

en el año 1868, en los autos "Luengo, Simón, y otros, por rebelión" (Fallos: 6:227), estableció el Tribunal que la Constitución en el art. 86 Ver Texto, inc $6^{\circ}$, autoriza al Presidente de la República, para indultar o conmutar las penas por delitos sujetos a la jurisdicción federal, previo informe del tribunal competente, lo que bien claro muestra que el ejercicio de ese derecho debe seguir al juzgamiento, en el que se ha de calificar, primero el delito y se ha de designar al delincuente y la pena; pues de otro modo, no podría indultarse en el sentido de la Constitución y previo informe judicial, a quien no es declarado culpable o conmutarse penas que no son conocidas ni han sido pronunciadas por la única autoridad a que está reservada esta función, quedando así, por último, invertido el orden natural de las funciones de los poderes públicos y burlados los propósitos de la Constitución. Al mantener ella el derecho de gracia en la forma que lo ha hecho, subordinándola a una tramitación especial, en que el juzgamiento preceda al indulto, ha querido sin duda, que éste evite o modifique el excesivo rigor que puede acompañar a la aplicación de la ley en ciertos casos y circunstancias, de que no debe darse cuenta un 
Juez; ha querido que todos y cada uno de los poderes cumplan con su deber en la esfera que les está marcada; que la moralidad se levante en alto; que la ley conserve siempre su prestigio, siendo ciegamente obedecida, y finalmente, que la conciencia que inspire el perdón al dispensar la pena, valga tanto como el mismo castigo y nada defraude a la justicia con que se aplica la ley en el proceso. (p. 2439).

Además, expresaron que, si el Presidente pudiese indultar, sin que se haya dictado una sentencia condenatoria, éste estaría ejerciendo funciones judiciales vedadas por la propia Constitución.

Comentando el fallo, Gelli (2013) sostuvo que en la causa, "la Corte Suprema de Justicia ha convalidado indirectamente aquellos indultos a procesados [...] pues el bolding de la sentencia rechazó el recurso por falta de legitimación de la presentante para cuestionar la medida" (p. 394).

\section{17. Caso "Causa artículo 10 de la ley 23.049 por hechos acaecidos en Provincias de Buenos Aires, Río Negro y Neuquén, bajo control operacional que habría correspondido al V Cuerpo del Ejército (Armada Argentina)" (Fallos: 323:2648)}

La Cámara Federal de Apelaciones de Bahía Blanca resolvió no hacer lugar a la declaración de inconstitucionalidad del decreto 1002/89 y sobreseyó definitivamente a los procesados en autos. Según narra la Corte, la Cámara Federal interviniente en el expediente de la referencia, dispuso desprender de las actuaciones las que correspondían a la fuerza armada y formar con ellas sub-causa por separado, con igual carátula, pero bajo otro número (11/88b). Así -continúa explicando el órgano judicial-, de las constancias agregadas y de la sentencia impugnada, surge que, en esta misma causa $\mathrm{N}^{\mathrm{o}} 11 / 88$ (b), se promovió el incidente $\mathrm{n}^{\circ} 386 / 89$ caratulado "Dr. Juan Carlos Wlasic (apoderado de Pedro Alberto Martinelli) en autos Aquino, Mercedes s/ denuncia (caso Martinelli-Oliva) s/ plantea inconstitucionalidad decreto 1002/89", en el que esa Corte Suprema, al tratar los agravios de índole constitucional planteados sobre la validez 
del decreto 1002/89, dictó sentencia el 14 de octubre de 1992 -registrada en Fallos: 315:2421- y por mayoría declaró que resultaba "indudable la facultad constitucional del titular del Poder Ejecutivo Nacional para indultar a personas sometidas a proceso" (v. considerando $4^{\circ}$ del fallo).

En consecuencia, estimó le resultaba inadmisible que en esta misma causa se pronunciara una nueva sentencia sobre el mismo planteo y que el apelante intente su revisión, puesto que con ello no sólo se desconoció la obligatoriedad del fallo de esta Corte y los límites a que estaba sujeta la jurisdicción del a quo, sino que se afectó la cosa juzgada emanada de esa decisión, lo que autoriza, en consecuencia, a declarar su nulidad en razón de que la estabilidad de las decisiones jurisdiccionales en la medida en que constituye un presupuesto ineludible de la seguridad jurídica, es exigencia de orden público y tiene jerarquía constitucional (v. considerando $6^{\circ}$ ).

Por lo expuesto, la Corte resolvió por unanimidad: $1^{\circ}$ ) Declarar procedente el recurso extraordinario y decretar la nulidad del pronunciamiento en lo vinculado a la constitucionalidad del decreto 1002/89 del Poder Ejecutivo Nacional y estar sobre el punto a lo resuelto en esta causa en "Aquino". $2^{\circ}$ ) Confirmar la sentencia impugnada en cuanto sobreseyó definitivamente en la causa y respecto de los imputados.

\section{18. Caso "Mazzeo, Julio Lilo y otros s/Rec. de casación e inconstitucionalidad" (Fallos: 330:3248)}

En el precedente "Mazzeo", el Máximo Tribunal pudo analizar la declaración de inconstitucionalidad del decreto $\mathrm{N}^{\mathrm{o}} 1002 / 89$. En esta oportunidad, la Corte no ingresó a juzgar la cuestión de fondo, es decir, no se expidió sobre la posibilidad de poder indultar a personas procesadas, entendiendo que la naturaleza de los delitos cometidos estaba fuera de la atribución constitucional. Es de destacar, tal como vimos "ut supra", que la Corte, con otra composición, había rechazado la inconstitucionalidad (causas "Rivero" y "Aquino"). 
Los hechos, en apretada síntesis, fueron los siguientes: en la causa se dictó el sobreseimiento a favor del imputado, por su presunta participación en hechos de homicidio, privación ilegítima de la libertad y torturas, entre otros delitos aberrantes, junto con personal de las Fuerzas Armadas y de Seguridad del Estado. Para decidirlo, se tuvo en cuenta que el imputado había sido indultado por Decreto $\mathrm{N}^{\mathrm{o}}$ 1002/89.

Con posterioridad, Sara de Castiñeiras, Iris Pereyra de Avellaneda, Floreal Avellaneda, Juan Manuel Castiñeiras y Ana María Astudillo, juntamente con sus representantes letrados y la Liga Argentina por los Derechos Humanos, solicitaron la declaración de inconstitucionalidad del mencionado decreto, mediante el cual, el Poder Ejecutivo Nacional indultó, entre otros, a Santiago Omar Riveros, por los hechos a él imputados en la ex causa 85 de la Cámara Federal de Apelaciones de San Martín.

El juez federal actuante hizo lugar a la presentación efectuada, declaró la invalidez constitucional del decreto y privó de efectos al sobreseimiento. El defensor de Riveros planteó la excepción de cosa juzgada en relación al sobreseimiento dictado, pues éste se encontraba firme. El auto fue revocado por la Cámara de Apelaciones. Luego, la Cámara Nacional de Casación Penal declaró la inconstitucionalidad del decreto que indultó al mencionado y esta decisión motivó la interposición del recurso extraordinario por parte de la defensa.

La Corte Suprema de Justicia entendió que existía una imposibilidad constitucional de indultar a autores y partícipes de delitos de lesa humanidad, pues dicho acto de gobierno conlleva de modo inescindible la renuncia a la verdad, la investigación, la comprobación de los hechos, la identificación de sus autores y la desarticulación de los medios y recursos eficaces para evitar la impunidad (Conforme considerando 29 del fallo de la mayoría).

En este orden, se cita a "La Corte Interamericana de Derechos Humanos": 
inadmisibles las disposiciones de amnistía, las disposiciones de prescripción y el establecimiento de excluyentes de responsabilidad que pretendan impedir la investigación y sanción de los responsables de las violaciones graves de los derechos humanos tales como la tortura, las ejecuciones sumarias, extralegales $o$ arbitrarias y las desapariciones forzadas, todas ellas prohibidas por contravenir derechos inderogables reconocidos por el Derecho Internacional de los Derechos Humanos" (CIDH - Serie C N ${ }^{\circ} 75$, Caso Barrios Altos, sentencia del 14 de marzo de 2001, párr. 41). Por su parte el juez García Ramírez, en su voto concurrente, señaló que las "disposiciones de olvido y perdón no pueden poner a cubierto las más severas violaciones a los derechos humanos" (párr. 11). (p. 3298 y 3299). En este mismo sentido, pero más enfáticamente en el caso "Almonacid", la Corte Interamericana señaló que los crímenes de lesa humanidad son serios actos de violencia que dañan a los seres humanos al golpear lo más esencial para ellos: su vida, su libertad, su bienestar físico, su salud y/o su dignidad. Son actos inhumanos que por su extensión y gravedad van más allá de los límites de lo tolerable para la comunidad internacional, la que debe necesariamente exigir su castigo. Agregó que por ello los crímenes de guerra y los crímenes de lesa humanidad, dondequiera y cualquiera que sea la fecha en que se hayan cometido, serán objeto de una investigación, y las personas contra las que existan pruebas de culpabilidad en la comisión de tales crímenes serán buscadas, detenidas, enjuiciadas y, en caso de ser declaradas culpables, castigadas. Señaló que por ello los Estados no adoptarán medidas legislativas ni tomarán medidas de otra índole que puedan menoscabar las obligaciones internacionales que hayan contraído con respecto a la identificación, la detención, la extradición y el castigo de los culpables de crímenes de guerra o de crímenes de lesa humanidad (Caso Almonacid Arellano y otros. CIDH - Serie C N ${ }^{\circ} 154$, sentencia del 26 de septiembre del 2006) (p. 3299). 
En otro importante pasaje de este fallo, en lo que respecta al objeto de nuestro trabajo, se indica lo siguiente:

lo cierto es que los delitos que implican una violación de los más elementales principios de convivencia humana civilizada, quedan inmunizados de decisiones discrecionales de cualquiera de los poderes del Estado que diluyan los efectivos remedios de los que debe disponer el Estado para obtener el castigo. Por ello tratándose el sub lite de la investigación de esa clase de delitos, cualquiera sea la amplitud que tenga el instituto del indulto, él resulta una potestad inoponible para este tipo de proceso, pues para el supuesto que se indultara a procesados partícipes de cometer delitos de lesa humanidad, ello implicaría contravenir el deber internacional que tiene el Estado de investigar, y de establecer las responsabilidades y sanción; del mismo modo, si se trata de indultos a condenados, igualmente se contraviene el deber que tiene el Estado de aplicar sanciones adecuadas a la naturaleza de tales crímenes. Por tal razón, resulta inocuo para la resolución del caso que hoy esta Corte entre a analizar si la facultad de indultar prevista en el artículo 99 de la Constitución Nacional abarca a los procesados o no, o si tiene características similares a la amnistía o no, pues en definitiva dicha potestad del Poder Ejecutivo, así como las amnistías, quedan reservadas para delitos de distinta naturaleza que los que se investigan en el sub lite. Por esas mismas razones, resulta innecesario dilucidar ahora si el objetivo que reserva nuestra Carta Magna al indulto es compatible con los fundamentos de carácter general esgrimidos en el decreto 1002/89 referentes a la supuesta necesidad de adoptar medidas que generaran las condiciones propicias para alcanzar la concordia, el mutuo perdón, la reconciliación, pacificación y la unión nacional (p. 3302 y 3303).

Asimismo, la Corte hizo referencia a la incompatibilidad que surge de contrastar los indultos por delitos de lesa humanidad y los instrumentos jurídicos internacionales, y a que el tema fuera tratado en dos precedentes: "Arancibia Clavel" (Fallos: 328:341) y "Simón" (Fallos: 328:2056). 
El Máximo Tribunal, en consecuencia, declaró la inconstitucionalidad del indulto y la nulidad de los efectos producidos.

Por último, cabe destacar que el fallo tuvo la disidencia de Fayt y Argibay. En el voto de la Magistrada se destaca un considerando:

Quiero dejar en claro desde ya que, a mi juicio, los indultos a personas procesadas son inconstitucionales porque implican una injerencia del Poder Ejecutivo en la jurisdicción exclusiva del Poder Judicial, lo cual atenta contra la división de poderes que sustenta nuestro sistema republicano de gobierno. Es verdad que, haciendo pie en el (actual) artículo 99.5 de la Constitución Nacional, una parte de la doctrina ha considerado factible realizar esta extensión; pero entiendo que tal interpretación amplía indebidamente la "magnanimidad" del Presidente de la Nación ya que la norma se refiere a indultar o conmutar penas, es decir, que permite un perdón discrecional. Nada hay que perdonar mientras no existe una condena que imponga pena, pues hasta entonces subsiste el principio de inocencia también consagrado por la Carta Magna. Sin embargo, mi opinión personal sobre la validez de estos indultos resulta una mera declaración de principios porque en la presente causa no puede dictarse un pronunciamiento judicial sobre ese punto sin decidir el agravio de la defensa fundado en la afectación de la cosa juzgada. ${ }^{8}$

\section{19. Caso "Díaz, Claudia Fabiana s/incidente de previo pronunciamiento (indulto)" (Fallos: 314:1440)}

En este fallo, la Corte aprovechó la oportunidad para establecer el alcance del control jurisdiccional del indulto, en los

8 Señala D’Alessio (2009): “En este nuevo pronunciamiento, la mayoría del alto tribunal afirmó que la decisión de cerrar ese proceso cercenó las obligaciones internacionales destinadas a comprobar los delitos denunciados, identificar a sus autores, cómplices y encubridores, e imponer las sanciones correspondientes, así como el derecho de las víctimas a un recurso eficaz para lograr tal cometido" (p. 1021). 
siguientes términos: "acto de gobierno y por ende de naturaleza política que no puede ser objeto de revisión judicial, sino que sólo cabe examinar las cuestiones jurídicas con él relacionadas".

Al respecto, Zaffaroni, E., Alagia, A. y Slokar, A. (2005, p. 889), sostienen que el control judicial se encuentra limitado en las siguientes situaciones: 1) cuando recaiga sobre penas no indultables ni conmutables; 2) cuando afecte el derecho de defensa o el derecho a la verdad reclamado por el procesado, y 3) cuando no tenga motivación alguna, pues no debe sustraerse la facultad para disponer inultos o conmutación de penas a la obligación de todo funcionario de dar razones fundadas de sus actos frente a la sociedad.

Por nuestra parte, de manera sucinta, siguiendo de cerca la doctrina del Tribunal Supremo español y de su Tribunal Constitucional, diremos que existe un núcleo que no es posible controlar, es decir, la decisión de indultar o no. Pero, una vez que se haya adoptado la decisión de hacerlo, el poder judicial se encuentra habilitado para analizar si los elementos o requisitos necesarios para su legítimo dictado concurren. En efecto, el indulto no es indiferente a la propia Constitución de la cual emana, la que le otorga esa juridicidad primigenia. Es que, en un Estado de derecho, no se puede aceptar una prerrogativa pública que, en su ejercicio, le permita al Presidente sustraerse totalmente de cualquier control por parte de los tribunales. ${ }^{9}$

Por esta razón, los indultos y las conmutaciones de pena son susceptibles de control jurisdiccional, en cuanto a los límites

9 En la sentencia del Tribunal Supremo del 11 de diciembre de 2012 (166/2001), se indicó lo siguiente: "El indulto, strictu sensu, no es un acto administrativo, ni menos un acto cuasireglado [...] pues el ejercicio del derecho de gracia constituye una facultad potestativa no susceptible de ser combatida ante la Jurisdicción Contencioso-administrativa, salvo cuando se incumplan los trámites establecidos para su adopción"; "de suerte que su concesión 0 denegación se conforma como un acto no sujeto al derecho administrativo". Por ello en la STS 23 de enero de 2013 (RC 443/2012) expuso que: "No resultan de aplicación al caso los requisitos que para los auténticos actos administrativos establece la Ley 30/1992, y entre ellos, y fundamentalmente, el de la motivación, que no es exigible en las decisiones que sobre el ejercicio del derecho de gracia de adopten por el Gobierno" 
y requisitos que deriven del propio texto de la Constitución (control que se da incluso frente a los actos considerados de "naturaleza política"). El constituyente define, mediante conceptos judicialmente controlables, los términos o requisitos previos a los que deben sujetarse el legítimo obrar, para comprobar que el Poder Ejecutivo ha actuado dentro del marco de constitucional y también -no es posible excluirlo- del marco de convencionalidad (Tribunal Supremo del Reino de España, 2005).

En consecuencia, el examen que le compete a los tribunales de justicia es, en primer lugar, el referido a los requisitos previstos en la Constitución, cuyas notas hemos visto en el capítulo anterior. Así, aun cuando el Presidente puede decidir a quién indulta o conmuta su pena y a quién no, lo cierto es que es la propia Constitución la que abre el control de la jurisdicción, a través de sus elementos reglados (es decir, sus requisitos).

Por último, es obvio que, a pesar de que las instituciones analizadas perduraron, las circunstancias históricas y sociales cambiaron sustancialmente. Consecuentemente, su aplicación no debe quedar anclada en el pasado, sino que debe adecuarse a los tiempos actuales, donde los principios emanados del sistema republicano resultan ser los que marcan la actuación de las autoridades públicas -por un lado- y la vigencia irrestricta de los derechos humanos por el otro. Al respecto, consideramos que, justamente, la manera de adecuar esa prerrogativa histórica, es someter la decisión presidencial al control judicial. Sólo de esta manera la aplicación del indulto y la conmutación de pena logran alejarse de su génesis monárquica y de los tiempos de las prerrogativas ilimitadas (Tribunal Supremo del Reino de España, 2013).

\section{20. Casos "Videla Jorge Rafael, Massera Emilio Eduardo s/ Recurso de Casación” (Fallos: 333:1657)}

En este caso, cuyos hechos aberrantes son de público conocimiento, la Corte declaró la inconstitucional del Decreto

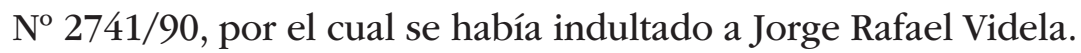


A fin de fundamentar la sentencia, los magistrados tomaron como base de su argumentación lo dicho en el caso "Mazzeo".

En igual sentido, y en la misma fecha, resolvió el caso "Martínez de Hoz", en los siguientes términos: "Que las cuestiones planteadas en el sub lite son sustancialmente análogas a las examinadas y decididas en la causa V.300.XLIV "Videla, Jorge Rafael $s$ /recurso de inconstitucionalidad de los decretos 1002/89 y 2745/90", sentencia de la fecha, a cuyas consideraciones y conclusiones se remite por razones de brevedad".

\section{En torno a la jurisprudencia reseñada en materia de indulto y conmutación de pena}

\section{IV.1. Observaciones}

Del compendio de fallos reseñados y analizados, podemos observar y/o afirmar lo siguiente:

1. Desde los primeros fallos referidos a la temática en estudio, la Corte se ocupó por distinguir con claridad las figuras del indulto y conmutación de penas respecto del instituto de la amnistía, dado que tanto los requisitos habilitantes como sus efectos se diferencian. Además, fundamentalmente buscó subrayar que la competencia asignada para dichas labores recaía en dos órganos distintos: Ejecutivo y Legislativo.

2. Constitucionalmente, el Ejecutivo sólo puede indultar a personas que hayan cometido delitos tramitados ante la justicia federal -conf. artículo 99, inciso $5^{\circ}$, Constitución Nacional-. Por su parte, los gobiernos provinciales pueden también hacerlo, pero sólo sobre los que tramiten ante la jurisdicción provincial. Luego de la reforma constitucional y del establecimiento de la Ciudad Autónoma de Buenos Aires, la atribución presidencial de indultar a condenados por tribunales ordinarios resulta cuestionable. Respecto a la amnistía, sólo puede ser efectuada por el Congreso de la Nación en uso de las facultades conferidas por el artículo 75, inciso 20. Es necesario aclarar que esta atribución 
no puede ser delegada al Poder Ejecutivo y que tampoco éste podría invocar el artículo 99, inciso 3, para dictarla.

3. Existe uniformidad en señalar que la falta del informe del Tribunal, en los términos previstos en el artículo 99, inciso $5^{\circ}$, de la Constitución, hace que el indulto dictado sea inconstitucional. Como requisito expreso de la carta magna, su omisión o defectuosa presentación (como, por ejemplo, omisión de los datos esenciales) ${ }^{10}$ acarrea su nulidad y no es posible que se integre con posterioridad. Es decir, no hay subsanación posible, debiéndose iniciar nuevamente el procedimiento. A este respecto, cabe aclarar que si bien la Constitución requiere que el Presidente se valga del informe del tribunal, este requisito, en modo alguno, lo obliga a seguir la opinión vertida por el órgano judicial.

4. Uno de los puntos neurálgicos respecto de las figuras analizadas es si, para su legitima emisión, el indulto o la conmutación de pena debe recaer únicamente en condenados o si, como dijo la Corte, puede alcanzar a procesados.

En apretada síntesis, teniendo en cuenta los límites del presente trabajo, las razones que nos llevan a adoptar la postura en favor de los condenados únicamente son las siguientes: 1). El artículo 99, inciso 5, debe ser interpretado junto al resto de las cláusulas constitucionales. Así, cobran relevancia los artículos 109 (prohibición de ejercer funciones judiciales por parte del Ejecutivo), 29 (prohibición de conceder la suma del poder público o facultades extraordinarias a gobiernos o persona alguna), 23 (imposibilidad del presidente, en casos de estado de sitio, de condenar por sí, ni aplicar penas) y 75 inciso 22 (Tratados internacionales de derechos humanos). Como corolario de ello, el poder ejecutivo no puede indultar a procesados pues se estaría entrometiendo ilegítimamente en las funciones

\footnotetext{
10 Al respecto, recordemos que la finalidad que se persigue con el informe completo es, precisamente, la de dotar al Poder Ejecutivo de la mayor información posible para que pueda adoptar una correcta decisión.
} 
del poder judicial. Ergo, sólo podrá indultar o conmutar cuando se haya concluido la labor judicial, es decir, frente a un condenado por sentencia firme, dictada por juez competente. 2). No hay delito ni responsable hasta que la sentencia condenatoria se encuentre pasada en autoridad de cosa juzgada. El procesado carece de dichos extremos, siéndole imposible asimilarlo por las diferencias estructurales de uno y otro. 3). El indulto recaído con anterioridad quebranta el derecho de toda persona a la presunción de inocencia, prevista en el artículo 18 de la Constitución Nacional, hasta tanto ser condenado por sentencia firme. ${ }^{11}$ 4). El indulto dictado con anterioridad, implica la renuncia voluntaria del Estado a la investigación de dicho delito. En casos de derechos humanos, como veremos a continuación, esta circunstancia es incompatible con la Convención Interamericana y la doctrina que, a partir de ésta, ha hecho la Corte Interamericana.

5. La Corte indicó que el indulto no depende de la voluntad del condenado, es decir, no puede rechazarlo, atento que la Corte entiende que es dictado, persiguiendo objetivos superiores a los intereses individuales.

En este punto, nuestra Corte ha seguido de cerca a su par norteamericana -doctrina sentada por la Corte Norteamericana en la causa "Burdick v. United States" (236 U.S., 79 del año 1915)-, y considera que no es un acto contractual.

6. La Corte Suprema entiende que los delitos de lesa humanidad no pueden ser objeto de indulto presidencial. Posición que compartimos porque, además del repudio personal que semejantes atrocidades nos generan, los propios hechos demuestran que estamos frente a delitos que afectan de una manera especial y particular a la sociedad en su conjunto. En ese orden, es inconstitucional el decreto por el cual se indultan graves delitos de lesa humanidad pues viola el compromiso internacional asumido por el Estado de reprimir tales conductas.

11 Bidart Campos (1993), p. 336-337. 
7. La Corte, intérprete final de la Constitución, no ha tenido oportunidad de expedirse respecto de los denominados delitos constitucionales (artículos 15, 22, 29, 36 y 119 de la Constitución Nacional). Si bien no es posible saber cómo se pronunciaría el Máximo Tribunal frente a indultos que tuvieran por objeto delitos de esa naturaleza, vale aclarar que nuestra postura es contraria a admitir la constitucionalidad de los indultos o conmutaciones que tengan por objeto hechos calificados como delitos constitucionales.

8. De los fallos referenciados, es posible afirmar que al indulto se lo consideraba una atribución discrecional-política de control limitado.

La mentada irrupción del bloque de constitucionalidad en la vida institucional argentina, ha marcado un cambio trascendental en la materia que, sumado a lo dicho por la Corte Interamericana en la especie, permite $-\mathrm{o}$, mejor dicho, obliga- un control más intenso de la prerrogativa en clave de defensa de los derechos humanos.

9. A partir de los fallos pronunciados por la Corte Suprema, es posible esbozar una definición del instituto del indulto como un acto de perdón (como potestad de carácter público, "Daleo"), individual y total ("Solís"), previsto como facultad privativa del Poder Ejecutivo en uso de sus facultades discrecionales ("Amborieta" y "Luengo"), por el cual una persona aun sin sentencia firme ("Ibáñez", "Daleo", "Riveros" y "Aquino"), ${ }^{12}$ puede acceder al beneficio sin que se le requiera su consentimiento ("Daleo"), para determinados delitos, excluyendo los delitos de lesa humanidad ("Videla", "Mazzeo" y "Aquino"), previo la elaboración de un informe del Tribunal interviniente ("Ibáñez").

\footnotetext{
12 Insistimos, que nuestra interpretación de la cláusula constitucional es contraria al criterio sentado. Cabe destacar, finalmente, que en el reciente fallo "Mazzeo", como se dijo oportunamente, el voto de la mayoría de la Corte Suprema consideró innecesario expedirse al respecto, pues entiende que el indulto resulta contrario a los tratados internacionales en materia de derechos humanos.
} 


\section{IV.2. Comentarios sobre la persistencia del artículo 99 inciso $5^{\circ}$ de la Constitución Nacional}

Debido a que los institutos pueden convertirse en un mecanismo legal para asegurar o cristalizar la impunidad de las personas que cometieron delitos atroces -tal como ocurrió en nuestro país durante la última dictadura cívico-militar (Decretos $\mathrm{N}^{\mathrm{o}} 1002 / 89,1003 / 89,1004 / 89$ y $2741 / 90$ ) - creemos que, mientras persista la cláusula constitucional que otorga al Poder Ejecutivo la facultad de indultar y/o conmutar penas, resulta sumamente necesario y conveniente limitar los delitos alcanzados por estas figuras (v. gr. delitos menores). Por otra parte, en relación con los indultos otorgados a los responsables de desaparición, tortura y muerte de personas durante la última dictadura, cabe recordar que la posterior declaración de la anticonstitucionalidad de los indultos otorgados resultó insuficiente: su dictado implicó un acto de menosprecio a la dignidad humana y un quiebre institucional, imposible de ser reparado en forma íntegra ulteriormente. Es por esta razón que, repetimos, creemos que es sumamente necesario limitar los delitos alcanzados por los institutos del indulto y la conmutación de penas.

Realizada esta aclaración, debemos enfatizar que el derecho internacional repudia la aplicación de estas figuras (y, podríamos agregar, también la de los institutos de prescripción y amnistía), frente a casos de graves -como ser las violaciones a los derechos humanos-, por ser justamente productores de actos de impunidad. Las violaciones a los derechos humanos, así como también los delitos universales, en tanto atentan contra la dignidad del ser humano, no pueden ser perdonados, acto contrario, se estaría perpetuando la impunidad. El Estado es responsable frente a una actuación de este tenor.

\section{IV.3. La incidencia de los tratados internacionales en los fallos de la Corte}

La jerarquización de los tratados internacionales en materia de derechos humanos, prevista en el artículo 75, inciso 22 de 
la Constitución, ha provocado una limitación sustancial de las figuras que podríamos asemejar a una reforma constitucional del inciso quinto. La Constitución vigente con anterioridad a la reforma de 1994, contaba con elementos para declarar la inconstitucionalidad de ciertos indultos, pero lo cierto es que, a partir de la incorporación y consideración de la actuación de la Corte Interamericana de Derechos Humanos, se ha desterrado definitivamente la posibilidad de indultar delitos de lesa humanidad. Asimismo, en otros casos, obliga a una reinterpretación acorde a los parámetros fijados (por ejemplo, auto-amnistía/ auto-indulto; delitos de corrupción; tráfico de personas o reducción a servidumbre, entre otros).

En ese orden, cabe analizar la relación entre el artículo 99, inciso 5, y la jurisprudencia de la Corte Interamericana de Derechos Humanos. Los Estados miembros de la CADH están obligados a investigar toda situación en la que se hayan violado los derechos humanos. La Corte lo ha dicho en los siguientes términos: "El Estado que deja impune las violaciones de derechos humanos estaría incumpliendo, adicionalmente, su deber general de garantizar el libre y pleno ejercicio de los derechos de las personas sujetas a su jurisdicción" [Corte IDH, Caso Cantoral Benavides, Reparaciones (Art. 63.1 CADH), sentencia de 3 de diciembre de 2001, Serie C, Nr. 88, párrafo 69].

Asimismo, la Corte Interamericana señaló:

toda violación de derechos humanos conlleva el deber del Estado de realizar una investigación efectiva para individualizar a las personas responsables de las violaciones y, en su caso, sancionarlas (...) Los Estados no deben ampararse en la falta de actividad procesal de los interesados para dejar de cumplir con sus obligaciones convencionales de investigar y sancionar las violaciones de derechos humanos. En el presente caso, el deber del Estado de investigar, identificar y sancionar a los responsables dentro del proceso penal en curso, constituye una obligación convencional que aquél debe cumplir y realizar ex officio en forma efectiva, independientemente 
de que las víctimas o sus representantes ejerzan o no las facultades que la legislación interna prevé para participar en el proceso abierto al efecto [Corte IDH, Caso Las Palmeras, Reparaciones (Art. 63.1 CADH), sentencia de 26 de noviembre de 2002, Serie C Nr. 96, párrafos 66-68].

Por lo expuesto, en línea con lo que estamos sosteniendo, la atribución de indultar o conmutar podrá ejercerse en la medida que dicha actuación no implique, en la práctica, la imposibilidad de iniciar o continuar una investigación puesta en marcha como consecuencia de violaciones a los derechos humanos protegidos por la Convención Interamericana. La víctima -insistimos- debe contar con la posibilidad, cierta y efectiva, de ocurrir a los tribunales de justicia y obtener, en tiempo razonable, una respuesta a su requerimiento. El impedimento al discernimiento sobre la verdad de los hechos acaecidos, implica una transgresión insoportable para la Constitución. De esta manera, la figura del indulto adopta un nuevo perfil acorde a nuestra actual configuración constitución (bloque constitucionalidad).

\section{IV.4. Comentario sobre los pasos previos a la aplicación del indulto}

A lo largo de los fallos analizados, observamos que la figura de la víctima del delito luce fuera de foco. ${ }^{13} \mathrm{Su}$ participación no existe en el procedimiento previo a la emisión del indulto. Creemos que, atentos a los cambios legislativos (Ley $\mathrm{N}^{\circ}$ 27.372) y jurisprudenciales dados en los últimos tiempos, se le debe otorgar una participación amplia, previa al dictado del acto por parte del Poder Ejecutivo.

Por otro lado, teniendo en consideración lo señalado, creemos que es pertinente establecer, de manera previa al dictado

\footnotetext{
13 El artículo 2 de la Ley $N^{0} 27.372$, considera víctima: a) A la persona ofendida directamente por el delito; b) Al cónyuge, conviviente, padres, hijos, hermanos, tutores o guardadores en los delitos cuyo resultado sea la muerte de la persona con la que tuvieren tal vínculo, o si el ofendido hubiere sufrido una afectación psíquica o física que le impida ejercer sus derechos.
} 
del acto, un espacio o ámbito de discusión, donde el Poder Ejecutivo se vea obligado a informar a la ciudadanía respecto de su voluntad de indultar o conmutar penas, comunicando -al mismo tiempo- las razones que justifican su dictado y promoviendo la participación de la ciudadanía, mediante audiencias públicas que garanticen la pluralidad de voces. De esta manera, la decisión se vería robustecida.

\section{Bibliografía}

Bidart Campos, G.J. (1993). Tratado Elemental de Derecho Constitucional Argentino. Tomo II. Buenos Aires: Ediar.

Bidart Campos, G.J. (1997). Manual de la Constitución Reformada. Tomo III, Buenos Aires: Ediar.

D’Alessio, A. J (2009). Código Penal de la Nación. Comentado y anotado, Tomo I. Buenos Aires: Editorial La Ley.

Frías Caballero, J. (1992). Indulto a procesados. Revista Jurídica Argentina La Ley, Número 1992:C.

Gelli, M. A. (2013). Constitución de la Nación Argentina: comentada y concordada. Tomo II. Buenos Aires: La Ley.

Ibarlucía, E. (1990). Inconstitucionalidad de los Decretos de "indulto" 1002/89, 1003/89 y 1004/89. Violación de la distribución de funciones entre los poderes del Estado que establece la Constitución Nacional. El Derecho. Jurisprudencia General, 135.

Lazzarini, J.L. (1989). Indulto presidencial durante el proceso. Revista Jurídica La Ley, Número 1989 D, (1116-1122).

Luna, F. (1993). Yrigoyen. Buenos Aires: Sudamericana.

Marienhoff, M.S. (2011). Tratado de Derecho Administrativo, Tomo II. Buenos Aires: Abeledo Perrot.

Decreto Presidencial del Estado Plurinacional de Bolivia No 3519 del 3 de abril de 2018 (publicación del 18/4/18). Fuente: http://www.gacetaoficialdebolivia.gob.bo/index.php/ normas/descargar/157659 [Fecha de consulta: 30/4/19].

Ramella, P. A. (1982). Derecho Constitucional. Buenos Aires: Depalma. 
Taglianetti, E.F. (2018). "El indulto y la conmutación de penas en la Constitución Nacional. Análisis constitucional, jurisprudencial y doctrinario". (Trabajo Final Integrado para acceder al título de especialista en Derecho Constitucional). Facultad de Ciencias Jurídicas y Sociales, Universidad Nacional de La Plata.

Zaffaroni, E., Alagia, A. y Slokar, A. (2005). Manual de Derecho Penal: Parte General. Buenos Aires: Ediar. 